\title{
European integration and external sustainability of the European Union: an application of the thesis of Feldstein and Horioka
}

\author{
João Sousa Andrade
}

\begin{abstract}
The Feldstein-Horioka thesis was considered one of the greatest puzzles in economics. Formulated to measure international capital mobility, it has known a process of immunization to be conformed to empirical evidence and respect econometric knowledge. We apply to EU countries a formulation of this thesis which is adequate to test external sustainability and measure international capital mobility. Applying appropriate econometric methods we can accept the hypothesis of external unsustainability for the EU before the enlargement. The enlargement allows the external sustainability of the new EU. The lesser mobility of capital in the countries of the enlargement must be considered as a positive shock on EU industry of financial services.
\end{abstract}

Keywords Feldstein-Horioka thesis · Capital mobility · Saving · Investment . External balance

JEL classification E21 E E22 - F21

Feldstein and Horioka (1980) (F-H) proposed a very simple and imaginative measure of international capital mobility. The results obtained with it originated one of the most important "puzzles" in economics. They caused

\footnotetext{
J. S. Andrade ( $\triangle)$

Grupo de Estudos Monetários e Financeiros, Faculdade de Economia,

Universidade de Coimbra, Coimbra, Portugal

e-mail: jasa@fe.uc.pt

J. S. Andrade

Centre d'Etudes en Macroéconomie et Finance Internationale,

Université de Nice Sophia Antipolis, Nice, France
} 
innumerable debates, where corrections and extensions were suggested, as well as positions which deny the interest of this thesis. I (Andrade 2007) presented the idea that the studies of this thesis are an example of a scientific practice as Karl Popper described it. In reaction to the problems of refutation, attempts of immunization were built. We can also recognize in this evolution a certain "methodological anarchism" à la Feyerabend (1993).

Accepting the positive effects of the mobility of capital for the development, a measurement of this mobility is very important. The results of the tests to confirm the thesis were responsible for its evolution, either at the level of the analysis or at the level of the econometric techniques. A theoretical position has been adapted to the econometric methods and allowed an interpretation in terms of external sustainability and capital mobility. We will apply these ideas to the countries of the EU, from 1993 to 2006. We also study subsets of these countries. We use the econometrics of nonstationary variables, as well as dynamic methods applied to panel data.

The paper was presented at the Conference "Contemporary Challenges of Theory and Practice in Economics" held at the Faculty of Economics, University of Belgrade on 26-29 September 2007.

\section{Thesis of Feldstein and Horioka and international capital mobility}

The mobility of capital is important, if not even essential, to allow an efficient allocation of capital, from the point of view of the diversity of its industrial uses as well as geographical location. An economy is internationally integrated if its flows of capital can enter and leave the country freely and if the national financial assets are good substitutes of the financial assets of other countries. The real and financial integration of less developed economies has the consequence of worsening the negative external balances. ${ }^{1}$ And a country, or a group of countries, whose growth is faster than that of the others will have, in theory, a more important imbalance of its external balance.

The development of the financial practices of protection against the risk will also contribute to the reduction of the national savings (Kimball 1990, Parker et al. 2002) and consequently to worsen external imbalance. Economic integration can lead, in the case of certain countries, or groups of countries, to external unsustainability of the economy. Independently of this last result, economists believe in the growth of the economy (Agenor $2003)^{2}$ as a result of the mobility of capital. As a consequence of this we are interested in a simple measurement of this mobility.

1 Or the average level of development (Blanchard and Giavazzi 2002).

2 For another point of view, see Edison et al. (2002). 
The idea behind the thesis of Feldstein and Horioka (1980) is quite simple: if an economy is internationally well integrated, then its accumulation of capital should not be constrained by national savings. ${ }^{3}$ That study was then refined by Feldstein (1983) and Feldstein and Bacchetta (1991). The equation which summarizes their work is the following:

$$
\frac{I}{Y}=\alpha+\beta \cdot \frac{S}{Y} \text {. }
$$

Feldstein and Horioka (1980) concluded that 85 to 95\% of the national savings was invested locally. Vis-à-vis these results, of absence of international mobility of capital, for developed economies, Obstfeld and Rogoff (2000) regarded this result as an enigma and as one of the six larger "puzzles" known in international economy.

The empirical result is difficult to accept. Since the beginning of the 1980 s, a reduction and elimination of regulations limiting international capital mobility has been seen. We became conscious that we live in a market which is international and the volatility of exchange rates precisely translates this mobility (Baxter and Crucini 1993). ${ }^{4}$ How can one accept that, contrary to our convictions about freedom of capital movements, the national saving can continue to constrain national investment?

The definition of $\mathrm{F}-\mathrm{H}$ of international capital mobility that the variations of domestic saving will not have effects on domestic investment, is the most demanding of the definitions (Frankel 1992). Taking into account the existence of exchange rate risk and the cost of this risk and also anticipations of real losses of the currency value, there will certainly be considerable differences between countries in the real interest rate. And consequently, one must expect that the coefficient of retention of $\mathrm{F}-\mathrm{H}(\beta)$ can have values far from unity. ${ }^{5}$

From a more formal point of view, Lemmen and Eijffinger (1998) showed that the conditions required by $\mathrm{F}-\mathrm{H}$ to evaluate a perfect integration are really leonine. It is consequently natural that one can arrive at different ideas on actual integration when other methods are used (Bayoumi 1990, Sachs 1981, Obstfeld 1986, Frankel 1991, Levy 1995, Frankel and MacArthur 1988, Popper 1990, Baxter and Crucini 1993, Bayoumi and MacDonald 1995, Goldberg et al. 2003). Methodologically this thesis is extremely powerful because it is exposed to its refutation. The problem, as so often in economics, is that its possible refutation resulted in the creation of

3 They have studied the OECD countries for the period 1960 to 1976, with cross-section data, to eliminate cyclical and endogenous problems. See also Bayoumi (1990).

4 For a world stock market, see Wheatley (1988); and for several European markets, Muller (2004).

5 For small economies the coefficient $\beta$ must be zero. For big economies it must be equal to the contribution of the country to the world stock of capital. A big economy will have a higher retention coefficient (Ho 2003). For Murphy (1986), a scale effect does not allow the F-H approach to measure capital mobility. 
auxiliary conditions to protect it, to immunize it (in the sense of Popper [2002]).

\section{The adaptation of F-H thesis to the results}

We can summarize in two tendencies the models which worked on the assumption of $\mathrm{F}-\mathrm{H}$ : the conciliation of their results with the accepted fact of the mobility of capital and the proposal of new methods more appropriate to the problem in question (Coakley et al. 1998). In the first case the authors are led to confirm two ideas: the international mobility of the capital was very high for the period of the traditional gold standard; it was considerable less for the period of the Bretton-Woods agreements, with an increasing tendency after the abandonment of this regime (Hogendorn 1998, Bayoumi 1990, Blanchard and Giavazzi 2002); at the same time, the mobility of the capital for the less developed countries is always higher than that obtained for developed countries (Coakley et al. 1999, Mamingi 1997, Chakrabarti 2006, Payne and Kumazawa 2006, Payne and Mohammadi 2006). Obviously there are results which contradict those (Lemmen and Eijfinger 1998, Rocha and Zerbini 2002) and Coakley et al. (1999) support the assumption that a low value for the coefficient of retention can be simply the result of weak economic policy measures in response to external imbalances. Other authors, such as Pomfret (1998), defend the idea according to which the test of $\mathrm{F}-\mathrm{H}$ is a reasonable measurement of the immobility of capital, but not of the mobility of capital. That the coefficient $\beta=0$, is a sufficient but not a necessary condition for the perfect mobility of capital. And a value of $\beta$ equal to 1 does not necessarily imply the immobility of capital (Jansen and Schulze 1996). With regard to the new econometric methods we must take into account the difficulty in comparing the former results, because a good share of them were obtained with stationary methods (Ho 2002) applied to nonstationary variables. ${ }^{6}$ We must apply nonstationary approaches, either with time series data or panel data, for the study of the puzzle of F-H (Coakley et al. 1998, 2004; Kim et al. 2005). Even if with these techniques of cointegration (CI) the contents of information of the thesis can be destroyed (as in the case of Jansen [1997]).

\section{Mobility, external sustainability, and cointegration}

Coakley et al. (1996), applying nonstationary methods, support the thesis according to which $\mathrm{F}-\mathrm{H}$ does not measure capital mobility but external

6 First-difference estimates are not efficient if the variables are cointegrated. Feldstein (1983), Feldstein and Bacchetta (1991), and Bayoumi (1990) have not respected this principle. 
sustainability. A coefficient close to the unit is nothing more than the result of the intertemporal budgetary constraint (Tesar 1991, Husted 1992, Jansen 1996, Jansen and Schulze 1996, Moreno 1997, Corbin 2004). A very simple development, starting from the accounting identity of the macro equality between global supply and demand, makes it possible to expose this argument. From the macro definition of product, $Y=C+I+$ $G+(X-M)$, where $C, G, X$, and $M$ represent private consumption, public consumption, exports, and imports, we deduce $(S-I) / Y=(X-M) / Y$. The stationarity of $(X-M) / Y$ is sufficient to prove external solvency (Obstfeld 1991, Alyousha and Tsoukis 2003, Coakley et al. 1996). ${ }^{7}$ This stationarity means that the series $I / Y$ and $S / Y$ are integrated of order 1 and cointegrated with the vector of cointegration $(1,-1)$. In this case, we cannot deduce anything with regard to the international capital mobility from the value of the long-term coefficient.

The econometrics of the nonstationary variables involves with it new questions. How "to deduce" the thesis from the coefficients obtained? Corbin (2004) proposes that if cointegration is not rejected, the adjustment coefficients in the ECM model represent the intensity of the capital mobility. But in this case we can also put the question of the policy interventions, in the short period, to push the economy towards its balance of long period. And so will the analysis be done compared to the capital mobility or to the effectiveness of the interventions? One will never be able to answer this question in a simple way (Fattouh 2005). Moreover, let us not forget that, with the increase in the number of observations, the probability of the stationarity of the external balance increases. ${ }^{8}$

Taylor (1996) and Banerjee and Zanghieri (2003) propose the equation ${ }^{9}$ $\Delta I_{t}=\alpha+\beta \cdot \Delta S_{t}+\gamma \cdot\left(S_{t}-I_{t}\right)$ to test for the presence of cointegration. ${ }^{10}$ For these authors, $\gamma$ represents the degree of capital mobility. Jansen (2000) proposes $\beta$ to measure short-period mobility and $\gamma$ the long-period mobility. Beyond an abusive simplification, the interpretation of the coefficients is obviously not clear.

\footnotetext{
7 If we want to be more precise we must add other variables to obtain the current account from the commercial account.

8 Taylor (2002) confirms the sustainability for 15 countries from 1870 to 1990 . - The ruptures in the series raise also particular problems. See Husted (1992), Ozmen and Parmaksiz (2003a, b) and Westerlund (2006).

9 Adapted here to the time series data.

10 What poses interrogations concerning the remainder of the C-I model and constraints of nullity of the coeffcients.
} 


\section{Empirical study}

\section{Presentation}

In this paper we will study the $26 \mathrm{EU}$ countries, except Luxembourg, ${ }^{11}$ for the period 1993 up to $2006 .{ }^{12}$ Holding in account the possible presence of unit roots and not wanting to fall into fallacious regressions (Baltagi and Kao 2000) we begin our empirical research with the study of the integration level of the variables.

\section{Stationarity tests}

We think that the most suitable assumption will be the heterogeneity of the coefficients, to hold in account the differences between the economies of the EU. Let us present in a summarized way the tests used.

(a) Levin and Lin (1993) - LL. ADF type statistics,

$$
\Delta y_{i, t}=\alpha_{0, i}+\rho_{i} \cdot y_{i, t-1}+\sum_{j=1}^{p} \gamma_{i} \cdot \Delta y_{i, t-1}+\varepsilon_{i, t}^{b} .
$$

Holding in account the criticism of Breitung (2000) we did not use the model with a single trend.

(b) Im et al. (2003) - IPS. Equation like LL, but the statistics is calculated from the average of the values obtained for the individual equations. The null hypothesis consists of $\rho_{i}=1$, for all the individuals, against $\rho_{i}<1$ for at least one individual.

(c) Breitung (2000) - UB. Like LL, except that one introduces a trend which is heterogeneous and nonhomogeneous.

(d) Hadri (2000) - H. Test of Kwiatkowski et al. (1992) type, with the trend as the only determinist variable. The starting equation for the case without trend:

11 The follwing countries were included in the study: Belgium (1), Czech Republic (2), Denmark (3), FR. Germany (4), Estonia (5), Greece (6), Spain (7), France (8), Ireland (9), Italy (10), Cyprus (11), Latvia (12), Lithuania (13), Hungary (14), Malta (15), Netherlands (16), Austria (17), Poland (18), Portugal (19), Slovenia (20), Slovakia (21), Finland (22), Sweden (23), United Kingdom (24), Bulgaria (25) and Romania (26). The groups PD and MD are composed as follows. PD: 1, 3, 4, 6, 7, 8, 9,10, 16, 17, 19, 22, 23, 24. MD: 2, 5, 11, 12, 13, 14, 15, 18, 20, 21, 25, 26. The total group of the economies will be identified by "Total". Therefore we have for Total the new EU, for PD the old EU, and for MD the economies of the enlargement process. In an enlarged version we have also included the data of the enlargement and the complete results of PMG estimation, for Total and PD economies. This last version is obtainable upon request.

12 We use the data of the macroeconomic statistics base of the European Commission, AMECO. 


$$
y_{i, t}=\alpha_{0, i}+\sum_{j=1}^{t} \xi_{i, t}+\eta_{i, t}
$$

with $\xi_{i, t}$ being a process IID $(0,1)$ and $\eta_{i t}$ stationary. The author proposes an LM test for stationarity.

Except for this last case, all the tests are of the ADF type. For the LL, IPS and $\mathrm{H}$ tests we used 1 lag to correct the natural presence of autocorrelation of the errors. The results of Tables 1 and 2 were obtained with the NPT software (Chiang and Kao 2002). The variables are the ratio of the national saving and the investment on the gross domestic product $(S / Y$ and $I / Y$ ).

As one can see, there are contradictory results. In any event we think that one can retain, in general, $I / Y$ as integrated of order 1 and $S / Y$ also as integrated of order 1 , but where the possibility of stationarity for Total and MD must be also considered.

With these results we must use the methods of FMOLS (fully modified estimator of OLS) of Phillips and Hansen (1990) and DOLS (dynamic least squares) of Saikkonen (1991) and Stock and Watson (1993). Kao and Chiang (2000) have shown that (a) the estimation error with OLS can be considerable with reduced samples; (b) in general the FMOLS estimate does not improve the OLS estimate; and (c) DOLS is the preferable method for obtaining long-period relations. To answer the problem of nonconvergence

Table 1 Tests of unit root of $I / Y$ and $S / Y$

\begin{tabular}{|c|c|c|c|c|c|c|}
\hline \multirow[t]{2}{*}{ Test } & \multicolumn{2}{|l|}{ Total } & \multicolumn{2}{|l|}{ PD } & \multicolumn{2}{|l|}{ MD } \\
\hline & $I / Y$ & $S / Y$ & $I / Y$ & $S / Y$ & $I / Y$ & $S / Y$ \\
\hline LL & $11.076^{* * *}$ & $4.958^{* * *}$ & 0.455 & 1.683 & $5.909^{* * *}$ & $8.760^{* * *}$ \\
\hline IPS & -0.247 & $-3.6^{* * *}$ & -2.233 & -0.841 & -0.111 & $-4.39^{* * *}$ \\
\hline UB & -1.131 & -0.18 & 0.545 & 0.954 & -1.074 & -0.303 \\
\hline $\mathrm{H}$ & $10.654^{* * *}$ & $9.386^{* * *}$ & $8.701^{* * *}$ & $7.033^{* * *}$ & $6.284^{* * *}$ & $4.747^{* * *}$ \\
\hline
\end{tabular}

Table 2 Tests of unit root of $\mathrm{d} I / Y$ and $d S / Y^{\mathrm{a}}$

\begin{tabular}{|c|c|c|c|c|c|c|}
\hline \multirow[t]{2}{*}{ Test } & \multicolumn{2}{|l|}{ Total } & \multicolumn{2}{|l|}{ PD } & \multicolumn{2}{|l|}{ MD } \\
\hline & $\mathrm{dI} / \mathrm{Y}$ & $\mathrm{dS} / \mathrm{Y}$ & $\mathrm{dI} / \mathrm{Y}$ & $\mathrm{dS} / \mathrm{Y}$ & $\mathrm{dI} / \mathrm{Y}$ & $\mathrm{dS} / \mathrm{Y}$ \\
\hline LL & $52.111^{* * *}$ & $28.44^{* * *}$ & $32.676^{* * *}$ & $15.607^{* * *}$ & $21.875^{* * *}$ & $28.374^{* * *}$ \\
\hline IPS & $-4.374^{* * *}$ & $-8.395^{* * *}$ & $-2.537^{* * *}$ & $-3.486^{* * *}$ & $-3.699^{* * *}$ & $-8.591^{* * *}$ \\
\hline UB & $-10.371^{* * *}$ & $-9.071^{* * *}$ & $-4.029^{* * *}$ & $-5.685^{* * *}$ & $-7.811^{* * *}$ & $-6.316^{* * *}$ \\
\hline $\mathrm{H}$ & 0.175 & $2.325^{* *}$ & -0.374 & $2.506^{* * *}$ & 0.661 & 0.716 \\
\hline
\end{tabular}

\footnotetext{
a The prefix " $d$ " means first difference
} 
and inefficiency of OLS estimators, Anderson and Hsiao (1981) proposed the use of instruments; ${ }^{13}$ however, the proposed estimator is convergent but nonefficient.

\section{Cointegration between saving and investment}

We propose the study of the presence of cointegration between investment and saving starting from the DOLS estimates. As we have a reduced the number of available observations (14) for each variable, we chose 1 lead and 1 lag of the first differences of S/Y, in the case of Total and MD. For PD we chose 2 periods because the results obtained with 1 alone for leads and lags was not reasonable (negative $\beta$ coefficient).

We have applied the Pedroni (1999) test to the errors of the cointegration relation whose null hypothesis is the absence of cointegration. From all the tests proposed by the author we have chosen the three last ones which, beyond the heterogeneity of the coefficients of cointegration, do not impose the presence of a common root to the alternative hypothesis. The results are in Table 3.

All the results reject the absence of cointegration. We can retain, in conclusion, that there is a long-period relation between investment and saving. We now will study the possibility of long-period homogeneous relations with heterogeneous short-term coefficients. This type of behaviour was presented by Pesaran et al. (1999), who named it the pooled mean group estimation (PMG). PMG estimates are convergent and efficient in the case of homogeneity of the coefficients of long term. Pesaran et al. (1999) proposed a Hausman test of PMG against the assumption of mean group estimation (MG) (see also Pesaran et al. 1996). I used the procedures of Pesaran et al. (1999). If one rejects the null hypothesis, PMG is not convergent.

We start from an assumption of long-period relation:

$$
I / Y=\theta_{0, i}+\theta_{1, i} \cdot S / Y+\mu_{i, t}
$$

with the formulation of short period, including the "error correction" values, given by:

Table 3 Tests of co-integration

\begin{tabular}{llrl}
\hline Statistics of Pedroni & Total & PD & \multicolumn{1}{l}{ MD } \\
\hline Group $\rho$ & $-19.51^{* * *}$ & $-11.48^{* * *}$ & $-16.40^{* * *}$ \\
Group t (NP) & $-7.18^{* * *}$ & $-4.46^{* * *}$ & $-5.90^{* * *}$ \\
Group t (P) & $-8.08^{* * *}$ & $-4.55^{* * *}$ & $-6.94^{* *}$ \\
\hline
\end{tabular}

13 A lag of order 2 of the dependent variable in levels and also in first differences. 
Table 4 PMG and MG estimations for Total (dependent variable, $I / Y$ )

\begin{tabular}{|c|c|c|c|c|c|c|c|c|}
\hline & \multicolumn{3}{|c|}{ PMG estimates } & \multicolumn{3}{|c|}{ MG estimates } & \multirow[t]{2}{*}{ h-test ${ }^{\mathrm{a}}$} & \multirow[t]{2}{*}{$\mathrm{p}$} \\
\hline & Coeff. & SE & t-ratio & Coeff. & SE & t-ratio & & \\
\hline \multicolumn{9}{|c|}{ Long-run coefficients } \\
\hline$S / Y$ & 1.236 & 0.094 & 13.194 & 0.861 & 0.490 & 1.758 & 0.61 & 0.44 \\
\hline \multicolumn{9}{|c|}{ Error correction coefficients } \\
\hline$\phi$ & -0.253 & 0.07 & -3.627 & -0.338 & 0.103 & -3.277 & & \\
\hline \multicolumn{9}{|c|}{ Short-run coefficients } \\
\hline$S / Y$ & 0.313 & 0.086 & 3.627 & 0.298 & 0.108 & 2.761 & & \\
\hline $\mathrm{d} I / Y(-1)$ & 0.101 & 0.058 & 1.744 & 0.115 & 0.092 & 1.256 & & \\
\hline $\mathrm{d} S / Y$ & -0.079 & 0.094 & -0.838 & -0.14 & 0.107 & -1.308 & & \\
\hline $\mathrm{d} S / Y(-1)$ & -0.023 & 0.047 & -0.497 & -0.042 & 0.075 & -0.564 & & \\
\hline Inpt & -0.005 & 0.005 & -0.981 & 0.012 & 0.026 & 0.457 & & \\
\hline
\end{tabular}

${ }^{a}$ The h-test is the Hausman test statistics with its associated $p$ value

$$
\begin{aligned}
\Delta I / Y_{i, t}= & \phi_{i} \cdot\left(I / Y_{i, t-1}-\theta_{0, i}-\theta_{1, i} S / Y_{i, t-1}\right)+\sum_{h=1}^{q} \delta_{1 h} \Delta I / Y_{i, t-h} \\
& +\sum_{j=1}^{p} \delta_{2 j} \Delta S / Y_{i, t-j}+\mu_{i, t}^{\prime} .
\end{aligned}
$$

The Schwarz criterion was used to select the number of lags, $q$ and $p$, in the dynamization of the last equation for a maximum of two lags. The results in Tables 4, 5, 6 summarize the estimates obtained for the various groups of countries. $\mathrm{d} I / Y(-1)$ and $\mathrm{d} S / Y(-1)$ represent the first lag of the first difference of natural $\log$ of $I / S$ and $S / Y$.

For the total of the 26 countries, the Hausman test does not reject the PMG model (Table 4). The long-period coefficient equal to the unit ${ }^{14}$ also cannot be rejected. The quality of the adjustment by the standard deviation of the estimate, $\sigma$, has values between 0.002 and 0.078, for Belgium and Latvia. There are problems of autocorrelation in the case of Poland, Estonia, and Romania. The specification test gives bad results for Belgium, Latvia, and Finland. The response to imbalances between investment and saving being reasonable (25\%) reflects at the same time considerable capital mobility. ${ }^{15}$

For the PD group of countries, the PMG model, once again, is not rejected compared to the MG model (Table 5). But now the long-term coefficient is not equal to $1 .{ }^{16}$ The limiting values of $\sigma$ are 0.002 for Belgium and 0.011 for Greece and Ireland. There are problems of autocorrelation for France, Ireland, and Holland. With regard to the problems of bad

14 The statistic $\mathrm{t}$ for $\phi=1$ is equal to 2.511 .

15 We follow the interpretation given by Taylor (1996) and Banerjee and Zanghieri (2003).

16 The statistic $t$ for $\phi=1$ is equal to 1.037 . 
Table 5 PMG and MG estmations for PD (dependent variable, $I / Y$ )

\begin{tabular}{|c|c|c|c|c|c|c|c|c|}
\hline & \multicolumn{3}{|c|}{ PMG estimates } & \multicolumn{3}{|c|}{ MG estimates } & \multirow[t]{2}{*}{ h-test ${ }^{\mathrm{a}}$} & \multirow[t]{2}{*}{$\mathrm{p}$} \\
\hline & Coeff. & SE & t-ratio & Coeff. & SE & t-ratio & & \\
\hline \multicolumn{9}{|c|}{ Long-run coefficients } \\
\hline$S / Y$ & 1.112 & 0.108 & 10.252 & 0.936 & 0.592 & 1.580 & 0.09 & 0.76 \\
\hline \multicolumn{9}{|c|}{ Error correction coefficients } \\
\hline$\phi$ & -0.184 & 0.084 & -2.199 & -0.286 & 0.172 & -1.663 & & \\
\hline \multicolumn{9}{|c|}{ Short-run coefficients } \\
\hline$S / Y$ & 0.205 & 0.093 & 2.199 & 0.346 & 0.168 & 2.060 & & \\
\hline $\mathrm{d} I / Y(-1)$ & 0.158 & 0.087 & 1.818 & 0.179 & 0.157 & 1.139 & & \\
\hline $\mathrm{d} S / Y$ & -0.046 & 0.078 & -0.592 & 0.162 & 0.134 & -1.208 & & \\
\hline $\mathrm{d} S / Y(-1)$ & 0.001 & 0.077 & 0.007 & -0.028 & 0.133 & -0.214 & & \\
\hline Inpt & -0.007 & 0.007 & -0.991 & -0.018 & 0.036 & -0.504 & & \\
\hline
\end{tabular}

${ }^{a}$ The h-test is the Hausman test statistics with its associated $p$ value

Table 6 PMG and MGestimations for MD (dependent variable, $I / V$ )

\begin{tabular}{|c|c|c|c|c|c|c|c|c|}
\hline & \multicolumn{3}{|c|}{ PMG estimates } & \multicolumn{3}{|c|}{ MG estimates } & \multirow[t]{2}{*}{ h-test ${ }^{a}$} & \multirow[t]{2}{*}{$\mathrm{p}$} \\
\hline & Coeff. & SE & t-ratio & Coeff. & SE & t-ratio & & \\
\hline \multicolumn{9}{|c|}{ Long-run coefficients } \\
\hline$S / Y$ & 2.466 & 0.297 & 8.315 & 0.773 & 0.835 & 0.926 & 4.71 & 0.03 \\
\hline \multicolumn{9}{|c|}{ Error correction coefficients } \\
\hline$\phi$ & -0.271 & 0.113 & -2.388 & -0.399 & 0.105 & -3.81 & & \\
\hline \multicolumn{9}{|c|}{ Short-run coefficients } \\
\hline$S / Y$ & 0.668 & 0.280 & 2.388 & 0.243 & 0.135 & 1.804 & & \\
\hline $\mathrm{d} I / Y(-1)$ & 0.021 & 0.087 & 0.248 & 0.041 & 0.082 & 0.506 & & \\
\hline $\mathrm{d} S / Y$ & -0.125 & 0.196 & -0.635 & -0.115 & 0.178 & -0.646 & & \\
\hline $\mathrm{d} S / Y(-1)$ & -0.059 & 0.059 & -1.000 & -0.059 & 0.059 & -1.00 & & \\
\hline Inpt & -0.066 & 0.029 & -2.296 & 0.047 & 0.034 & 1.359 & & \\
\hline
\end{tabular}

${ }^{a}$ The h-test is the Hausman test statistics with its associated $\mathrm{p}$ value

specification, Belgium and Finland do not reject this type of problem. At the same time, the process of adjustment is considerably slow (0.184), which can also be seen as representing strong capital mobility.

For the PMG model of the MD group of countries we cannot reject the assumption of a long-term coefficient equal to the unit (Table 6). ${ }^{17}$ But the PMG model must be rejected compared to the MGE model. And this last model rejects, in turn, the possibility of a long-term homogeneous relation.

In conclusion the assumption of homogeneity was accepted in the case of all the economies (Total) and also for the PD group. But only for the first case we can retain the long-term coefficient equal to the unit. If the

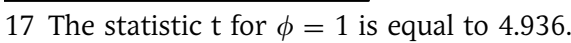


sustainability cannot be retained for PD, it can, on the other hand, be retained for the new EU.

\section{Dynamization of the F-H relation}

As our results for the countries of the enlargement were not encouraging, we also tested ADL models (Johnston and Dinardo 1997, pp. 244-248) to arrive at long-term relations between the two variables. To obtain efficient estimators with the number of observations available, we must use the method of Arellano and Bond (1991). Of all the simulated assumptions we retained only those of Tables 7 and 8. AR(2) is an autoregression test of order 2 corresponding to the $\mathrm{m}_{2}$ test of Arellano and Bond (1991).

$\mathrm{AB} 1$ and $\mathrm{AB} 2$ mean the first and the second step of the Arellano and Bond method. In Table 8 all estimates were made with fixed effects. In the case of PD we have only used lags from 2 to 6 for the instrumental variables in the application of Arellano and Bond methodology, AB1(6). This option is justified by the data available for the study of this group of countries.

We did not obtain any result rejecting the null hypothesis for the coefficient of $S / Y$ for the countries of the third group, MD.

For all EU countries, even if only for the second estimate the Sargan test is suitable, we can never reject the hypothesis of a long-term coefficient equal to 1 . The standard deviation of the errors has a very low value for the four estimates. The estimation for the sample PD is still better from the point of view of the adjustment. But for this group of countries we can reject the hypothesis of a long-term coefficient equal to 1, its value ranges between 0.23 and 0.29. The test of Sargan justifies the instruments used.

For the MD group it was not possible to obtain a dynamic model with the rejection of the null hypothesis of the saving coefficient. We have tested

Table 7 Dynamization of F-H model for Total

\begin{tabular}{lcccc}
\hline Total & $\mathrm{AB} 1$ & $\mathrm{AB} 2$ & $\mathrm{AB} 1$ & $\mathrm{AB} 1$ \\
\hline $\mathrm{d} I / Y(-1)$ & $0.936^{* * *}$ & $0.803^{* * *}$ & $0.978^{* * *}$ & $0.956^{* * *}$ \\
$\mathrm{~d} I / Y(-2)$ & $-0.165^{* *}$ & & $-0.137^{* *}$ & $-0.137^{*}$ \\
$\mathrm{~d} S / Y$ & $0.131^{* *}$ & $0.093^{*}$ & $0.163^{* *}$ & $0.148^{*}$ \\
Constant & 0.0002 & 0.0003 & 0.005 & \\
AR(2) & 1 & -0.265 & 0.716 & 0.739 \\
Sargan & $124^{* * *}$ & 24.66 & $111.9^{* * *}$ & $113^{* * *}$ \\
Wald & $80.2^{* * *}$ & $46.88^{* * *}$ & $137^{* * *}$ & $115^{* * *}$ \\
$\phi=1$ & 0.489 & 0.626 & 0.002 & 0.018 \\
$\sigma$ & 0.018 & 0.017 & 0.018 & 0.098 \\
$\mathrm{~T} \_\mathrm{M}^{\mathrm{a}}$ & - & - & yes & yes \\
\hline
\end{tabular}

${ }^{\mathrm{a}} \mathrm{T} \_\mathrm{M}$ means temporal dummy variables introduced to take into account the presence of shocks on the countries of the sample 
Table 8 Dynamization of F-H model for PD

\begin{tabular}{lcccc}
\hline $\mathrm{PD}$ & $\mathrm{AB} 1(6)$ & $\mathrm{AB} 1(6)$ & $\mathrm{AB} 1$ & $\mathrm{AB} 1$ \\
\hline $\mathrm{dI} / \mathrm{Y}(-1)$ & $0.936^{* * *}$ & $0.993^{* * *}$ & $0.941^{* * *}$ & $1.008^{* * *}$ \\
$\mathrm{dI} / \mathrm{Y}(-2)$ & $-0.485^{* * *}$ & $-0.454^{* * *}$ & $-0.487^{* * *}$ & $-0.459^{* * *}$ \\
$\mathrm{dS} / \mathrm{Y}$ & $0.155^{* * *}$ & $0.108^{* *}$ & $0.158^{* * *}$ & $0.106^{* *}$ \\
$\mathrm{AR}(2)$ & -0.076 & -0.261 & -0.106 & -0.292 \\
Sargan & 113 & 122.9 & 114 & 122 \\
Wald & & $8246^{* * *}$ & & $7692^{* * *}$ \\
$\phi=1$ & $16.2^{* * *}$ & $18.9^{* * *}$ & 15.1 & $19.9^{* * *}$ \\
& 0.282 & 0.235 & 0.289 & 0.234 \\
& 0.008 & 0.008 & 0.008 & 0.008 \\
EFRN $^{\mathrm{a}}$ & - & yes & - & yes \\
\hline
\end{tabular}

${ }^{a}$ EFRN means excluded dummy variables by countries which do not reject the null hypothesis in order to obtain a more parsimonious model

Table 9 Random-effects model for MD

\begin{tabular}{lll}
\hline MD random effects & Coefficient & Standard deviation \\
\hline Constant & $0.196^{* * *}$ & 0.015 \\
$S / Y$ & $0.158^{* *}$ & 0.07 \\
$\sigma$ & 0.043 & \\
\hline
\end{tabular}

models with the method of Arellano and Bond (1991), Anderson and Hsiao (1981) and also DOLS with common trends, individual trends and also changes of interception. The only result with a value different from zero for the saving coefficient was obtained with a static model without dummy variables beyond the interception (Table 9). The test for the rejection of the pooled (Pool) model against the fixed-effects (FE) model gives $\mathrm{F}_{11,155}=11.3$ and so we accept the FE model. The Breusch-Pagan test $\left(\chi_{1}^{2}=108.0\right)$ led in turn to accept the random-effects (RE) model and the test of Hausman $\left(\chi_{1}^{2}=12.3\right)$ to retain the fixed-effects model. Our problem is that the fixedeffects model does not reject the nullity of the saving coefficient. For this reason we have finally retained the random-effects estimate.

The most interesting aspect of this estimate is the reduced value of the saving coefficient (0.16) which means a considerable international capital mobility, and so a reduced constraint of national savings on investment.

\section{Conclusions}

Concerning the puzzle of $\mathrm{F}-\mathrm{H}$, it is remarkable that many economists continue to be interested in it and the number of published papers does not cease to grow. One of the reasons must be the simplicity of its application and the process of permanent adaptation of the main thesis. According to recent authors who have proposed new explanations for the 
thesis, we have studied the countries of the EU from the point of view of the external sustainability and capital mobility.

Taking as the most probable that the variables are I(1), and after the confirmation of the presence of cointegration, we tested PMG models against the MGE models and we tested also the dynamization of the F-H relation. The results obtained confirm the external sustainability of the new EU. For the group of old countries of the EU (PD) the PMG model does not confirm the external sustainability. With these results we can say that the enlargement has been beneficial for the external sustainability of the EU. The dynamisation of the original F-H relation confirms these results about the external sustainability. With regard to the mobility of capital, the PMG model confirms the idea of a strong mobility for the EU and an even stronger mobility in the first group (PD). This mobility is also confirmed by the dynamization of the $\mathrm{F}-\mathrm{H}$ relation. For the countries of the enlargement (MD) the only interesting model is a random-effects static model confirming a strong mobility of capital. Therefore we can also conclude that the enlargement represents a positive shock for the financial services industry of the EU. With regard to the countries of the enlargement (MD), we think that a finer research for homogeneous subgroup behaviour is justified to say more about their behaviour in terms of external sustainability.

Acknowledgment I thank an anonymous referee for his most helpful comments on the previous version of this paper.

\section{References}

Agenor PR (2003) Benefits and costs of international financial integration: theory and facts. World Economy 26:1089-1118

Alyousha A, Tsoukis C (2004) A re-examination of saving-investment relationships: cointegration, causality, and international capital mobility. In: Agiomirgianakis G, Biswas T, Coakley J, Tsoukis C (eds) Aspects of globalization: macroeconomic and capital market linkages in the integrated world economy. Kluwer Academic, London

Anderson TW, Cheng H (1981) Estimation of dynamic models with error components. Journal of the American Statistical Association 76:598-606

Andrade JS (2007) La thèse de Feldstein-Horioka: une mesure de la mobilité internationale du capital. Panoeconomicus 54:53-67

Arellano M, Bond S (1991) Some tests of specification for panel data: Monte Carlo evidence and an application to employment equations. Review of Economic Studies 58:277-297

Baltagi B, Kao C (2000) Nonstationary panels, cointegration in panels and dynamics panels: a survey. In: Baltagi B (eds) Nonstationary panels, panel cointegration, and dynamic panels. Advances in econometrics. vol 14. Elsevier, Amsterdam, pp 7-51

Banerjee A, Zanghieri P (2003) A new look at the Feldstein-Horioka puzzle using an integrated panel. Working Paper 2003-22. Centre d'Etudes Prospectives et d'Information Internationales, Paris

Baxter M, Crucini M (1993) Explaining saving-investment correlations. American Economic Review 83:416-436

Bayoumi T (1990) Saving-investment correlations: immobile capital, government policy, or endogenous behavior. IMF Staff Papers 37:360-387

Bayoumi T, MacDonald R (1995) Consumption, income and international capital market integration. IMF Staff Papers 42:552-576 
Blanchard O, Giavazzi F (2002) Current account deficits in the Euro area: the end of the Feldstein-Horioka puzzle? Brookings Papers in Economic Activity 2 2002:147-186

Breitung J (2000) The local power of some unit root tests for panel data. In: Baltagi B (eds) Nonstationary panels, panel cointegration, and dynamic panels. Advances in econometrics. vol 14. Elsevier, Amsterdam, pp 161-178

Chakrabarti A (2006) The saving-investment relationship revisited: new evidence from multivariate heterogeneous panel cointegration analyses. Journal of Comparative Economics 34:402-419

Chiang M, Kao C (2002) Nonstationary panel time series using NPT 1.3 - a user guide. Maxwell School of Syracuse University, Syracuse, NY, http://www.maxwell.syr.edu/maxpages/ faculty/cdkao/working/npt.html

Coakley J, Kulasi F, Smith R (1996) Current account solvency and the Feldstein-Horioka puzzle. Economic Journal 106:620-627

Coakley J, Kulasi F, Smith R (1998) The Feldstein-Horioka puzzle and capital mobility: a review. International Journal of Finance and Economics 3:169-88

Coakley J, Hasan F, Smith R (1999) Saving, investment, and capital mobility in LDCs. Review of International Economics 7:632-640

Coakley J, Fuertes AM, Spagnolo F (2004) Is the Feldstein-Horioka puzzle history? Manchester School 72:569-590

Corbin A (2004) Capital mobility and adjustment of the current account imbalances: a bounds testing approach to cointegration in 12 countries (1880-2001). International Journal of Finance and Economics 9:257-276

Edison H, Ricci L, Slok T (2002) International financial integration and economic growth. Journal of International Money and Finance 21:749-776

Fattouh B (2005) Capital mobility and sustainability: evidence from US current account data. Empirical Economics 30:245-53

Feldstein M (1983) Domestic saving and international capital movements in the long run and the short run. European Economic Review 30:735-752

Feldstein M, Bacchetta P (1991) Domestic saving and international investment. In: Bernheim D, Shoven J (eds) National saving and economic performance. Chicago University Press, Chicago

Feldstein M, Horioka C (1980) National saving and international capital flows. Economic Journal 90:314-329

Feyerabend P (1993) Against method. Verso, London

Frankel J (1991) Quantifying international capital mobility in the 1980s. In: Bernheim B, Shoven $\mathrm{J}$ (eds) National saving and economic performance. University of Chicago Press, Chicago

Frankel J (1992) Measuring international capital mobility: a review. American Economic Review 82:197-202

Frankel J, MacArthur A (1988) Political vs. currency premia in international real interest rate differentials. European Economic Review 32:1083-1121

Goldberg L, James L, Okunev J (2003) Has international financial integration increased. Open Economies Review 14:299-317

Hadri K (2000) Testing for stationarity in heterogeneous panel data. Econometrics Journal 3:148-161

Ho TW (2002) A panel cointegration approach to the investment-saving correlation. Empirical Economics 27:91-100

Ho TW (2003) The saving-retention coefficient and country-size: the Feldstein-Horioka puzzle reconsidered. Journal of Macroeconomics 25:387-396

Hogendorn C (1998) Capital mobility in historical perspective. Journal of Policy Modeling 20:141-161

Husted S (1992) The emerging U.S. current account deficit in the 1980s: a cointegration analysis. Review of Economics and Statistics 74:159-166

Im K, Hashem Pesaran M, Shin Y (2003) Testing for unit roots in heterogenous panels. Journal of Econometrics 115:53-74

Jansen W (1996) Estimating saving-investment correlations: evidence for OECD countries based on an error correction model. Journal of International Money and Finance 15:749-781 
Jansen W (1997) Can the intertemporal budget constraint explain the Feldstein-Horioka puzzle? Economics Letters 56:77-83

Jansen W (2000) International capital mobility: evidence from panel data. Journal of International Money and Finance 19:507-511

Jansen W, Schulze G (1996) Theory-based measurement of the saving-investment correlation with an application to Norway. Economic Inquiry 34:116-132

Johnston J, Dinardo J (1997) Econometric methods. McGraw-Hill, New York

Kao C, Chiang MC (2000) On the estimation and inference of a cointegrated regression in panel data. In: Baltagi B (eds) Nonstationary panels, panel cointegration, and dynamic panels. Elsevier, Amsterdam, pp 179-222

Kim H, Oh KY, Jeong CW (2005) Panel cointegration results on international capital mobility in Asian economies. Journal of International Money and Finance 24:71-82

Kimball M (1990) Precautionary saving in the small and in the large. Econometrica 58:53-73

Kwiatkowski D, Phillips P, Schmidt P, Shin Y (1992) Testing the null hypothesis of stationarity against the alternative of a unit root. Journal of Econometrics 54:159-178

Lemmen J, Eijffinger S (1998) The quantity approach to financial integration: the FeldsteinHorioka criterion revisited. In: Lemmen J (eds) Integrating financial markets in the European Union. Edward Elgar, Cheltenham

Levin A, Lin CF (1993) Unit roots in panel data: new results. Discussion Paper 93-56. University of California, San Diego

Levy D (1995) Investment-saving comovement under endogenous fiscal policy. Open Economies Review 6:237-254

Mamingi N (1997) Saving-investment correlations and capital mobility: the experience of developing countries. Journal of Policy Modeling 19:605-616

Moreno R (1997) Saving investment dynamics and capital mobility in the U.S. and Japan. Journal of International Money and Finance 16:837-863

Muller P (2004) European financial market integration. World Economics 5:83-130

Murphy R (1986) Productivity shocks, non-traded goods and optimal capital accumulation. European Economic Review 30:1081-1095

Obstfeld M (1986) Capital mobility in the world economy: theory and measurement. CarnegieRochester Conference Series on Public Policy 24:1-24

Obstfeld M (1991) Comment on D. Levy's "Investment-saving comovement, capital mobility, and fiscal policy". Presentation at NBER Conference on Macroeconomic Effects of Fiscal Policy, Cambridge, Mass

Obstfeld M, Rogoff K (2000) The six major puzzles in international macroeconomics: is there a common cause. NBER Working Paper 7777. National Bureau of Economic Research, Cambridge, Mass

Özmen E, Parmaksiz K (2003a) Exchange rate regimes and the Feldstein-Horioka puzzle: the French evidence. Applied Economics 35:217-222

Özmen E, Parmaksiz K (2003b) Policy regime change and the Feldstein-Horioka puzzle: the UK evidence. Journal of Policy Modeling 25:137-149

Parker J, Jonathan A, Preston B (2002) Precautionary saving and consumption fluctuations. NBER Working Paper 9196. National Bureau of Economic Research, Cambridge, Mass

Payne J Kumazawa R (2006) Capital mobility and the Feldstein-Horioka puzzle: re-examination of less developed countries. Manchester School 74:610-616

Payne J, Mohammadi H (2006) Capital mobility and savings-investment correlations: panel data evidence from transition economies. Applied Economics Letters 13:611-613

Pedroni P (1999) Critical values for cointegration tests in heterogeneous panels with multiple regressors. Oxford Bulletin of Economics and Statistics 61(Suppl):653-678

Pesaran MH, Smith R, Im KS (1996) Dynamic linear models for heterogenous panels. In: Mátyás L, Sevestre P (eds) The econometrics of panel data. Kluwer Academic, Dordrecht, pp 145-195

Pesaran MH, Shin Y, Smith R (1999) Pooled mean group estimation of dynamic heterogenous panels. Journal of the American Statistical Association 94:621-634

Pesaran MH, Shin Y, Smith R (1999) Program and data (pooled mean group estimation). University of Cambridge, Cambridge

Phillips P, Hansen B (1990) Statistical inference in instrumental variables regression with I(1) processes. Review of Economic Studies 57:99-125 
Pomfret R (1998) Measuring the degree of capital mobility: what does the Feldstein-Horioka equation test? In: Dahiya SB (eds) International economics, financial economics. The current state of economic science, vol 3. Spellbound, Rohtak, India

Popper H (1990) International capital mobility: direct evidence from long-term currency swaps. International Finance Discussion Paper 386. Board of Governors of the Federal Reserve System, Washington, DC

Popper K (2002) Conjectures and refutations. Routledge, London

Rocha F, Zerbini B (2002) Using a panel structure to discuss the Feldstein-Horioka puzzle in developing countries. Seminário de Economia da Fundação Getúlio Vargas, 6 June 2002. Escola de Pós-Graduação em Economia, Fundação Getulio Vargas, Rio de Janeiro

Sachs J (1981) The current account and macroeconomic adjustment. Brookings Papers on Economic Activity 1 1981:201-268

Saikkonen P (1991) Asymptotically efficient estimation of cointegration regressions. Econometric Theory 7:1-21

Stock J, Watson R (1993) A simple estimator of cointegrating vectors in higher order integrated systems. Econometrica 61:783-820

Taylor A (1996) International capital mobility in history: the saving-investment relationship. NBER Working Paper 5743. National Bureau of Economic Research, Cambridge, Mass

Taylor A (2002) A century of current account dynamics. Journal of International Money and Finance 21:725-748

Tesar L (1991) Savings, investment, and international capital flows. Journal of International Economics 31:55-78

Westerlund J (2006) Testing for panel cointegration with multiple structural breaks. Oxford Bulletin of Economics and Statistics 68:101-132

Wheatley S (1988) Some tests of international equity integration. Journal of Financial Economics 21:177-112 